been trying to discover some other method of arriving at the same end without producing flame.

Amongst these may be.mentioned in this place :-

I. Improvements in wedging processes. A long iron wedge, placed in a previously drilled bore-hole between two strips of iron with flat faces and convex backs, is forced inwards by means of a sarew or by hydraulic pressure.

2. Improvements in blasting processes. (a) A gun powder cartridge is placed in an ordinary bore-hole, but a cylinder filled with water occupies most of the remainder of the hole instead of the usual tamping of rubbish (MacNab's Patent). (b) A dynamite cartridge inclosed in a waterproof bag is placed in the interior of the water cylinder of the last case (Abel's modification).

(The writer conducted a long series of experiments with dynamite water-cartridges for Prof. Abel and the Commissioners on Accidents in Mines, and the results will doubtless be published for the benefit of other investigators. In these experiments the mouth of the shothole was always situated in the centre of one side of a cubical bag containing 64 cubic feet of explosive gas.)

3. The caustic lime process, which forms the principal subject of the present note.

Although the proposal to employ caustic lime in this manner is not quite new, its first successful application has been made by Messrs. Smith and Moore, at Shipley Collieries in Derbyshire, where, thanks to the courtesy of these gentlemen, we lately saw it in operation under the superintendence of one of them. The seam of coal which is known as the Derbyshire Deep Hard, consists of three beds in immediate contact with each other. The top bed -one foot thick - is of inferior quality, and is left for a roof and permanently lost. The middle bed -2 feet 10 inches thick-produces good marketable coal in large blocks, and constitutes the object of working. The bottom bed-7 inches thick-together with a bed of soft shale Io inches thick, serves as a holing. The method of working is longwall-the faces being straight, and each about 100 yards long. The holing is carried in to a depth of about $3 \frac{1}{2}$ or 4 feet under the roal ; and while it is being done, the front of the mass which it is intended to detach is supported upon short timber props (sprags) placed at distances of six feet apart.

After the holing is completed a series of horizontal holes three inches in diameter are drilled close to the roof to a depth of three feet or so. These holes are also about six feet apart. Seven cylindrical blocks of caustic lime, each $2 \frac{1}{2}$ inches in diameter by $4 \frac{1}{4}$ inches long are placed in each hole. They are prepared by grinding burnt lime to a fowder, and then compressing it into blocks of the required shape and dimensions under a hydraulic press. They are, naturally, kept and carried in air-tight boxes. There is a groove in each block parallel with its axis, and large enough to receive a pipe $\frac{1}{2}$ inch in diameter. The grooves are kept uppermost in the bore-hole. An iron pipe $\frac{1}{2}$ inch in diameter, a few inches longer than the length of the hole, provided with a stop-cock at its outer end, and with a cloth bag drawn over its inner end, is inserted into the groove of the first block and then forms a guide for the others. Outside the last block the hole is firmly tamped first with paper, and then with rubbish.

After all the holes have been charged, a quantity of water, said to be equal in bulk to that of the caustic lime already occupying the hole, is forced into each in succession through the iron pipe. This is done by means of a hand-pump attached to a bucket, and provided with a short length of flexible hose. The stopcock of each pipe is immediately closed after the water has been introduced. This operation occupies about one minute for each hole, and the two men who carry it out pass along the face from one end to the other.

A sound as of steam escaping under a high pressure is now heard, and here and there the tamping is blown out.
Then follows the well-known sound of what is technically called "working "while the coal is being separated from the upper bed by the pressure of the expanding lime. After the lapse of a few minutes it is found that the whole mass of coal is resting upon the sprags, and these have only to be knocked out in order that it may fall in the face.

The time required for the various operations may be divided as follows :-Drilling, 12 minutes; charging, 4 minutes; introducing water, I minute; total, 17 minutes for each bore-hole.

Although this system is undoubtedly successful in the circumstances under which it has been applied, it would be a mistake to assume that it is likely to have anything but a limited application. For it has been found by experiment to be incapable of breaking down a hard rock or shale roof, such as is to be met wih in many mines in which blasting is required for that purpose, and for that alone.

Let us take the case of Risca Colliery, so notorious for great explosions, in which the roof of the roadways requires to be ripped down in order to get sufficient height for haulage purposes. The last great explosion took place at the beginning of the present year: but, as only the four men who were underground at the time were killed, it passed almost without remark. Nevertheless, the damage done by it was immense; coal-getting operations had to be suspended for over a month, and one large district of workings was entirely wrecked and was permanently abandoned.

And what were the circumstances under which all thi took place? Four men were firing four shots in the principal intake air-way in the presence of dry coal-dust. One of these shots blew out its tamping. The men were all found in the intake air-way with their safety-lamps uninjured.

This is a case which the objectors to the coal-dust theory both in this country and abroad would do well to ponder carefully.

William Galloway

\section{THE COLOURS OF FLOWERS, AS ILLUS- TRATED BY THE BRITISH FLORA}

I.

\section{General Law of Progressive Modification}

PETALS are in all probability originally enlarged and flattened stamens, which have been set apart for the special work of attracting insects. It seeins likely that all flowers at first consisted of the central organs alone - that is to say, of a pistil, which contains the ovary with its embryo seeds; and of a few stamens, which produce the pollen. But in those plants which took to fertilisation by means of insects-or, one ougbt rather to say, in those plants which insects took to visiting for the sake of their honey or pollen, and so unconsciously fertilisingthe flowers soon began to profuce an outer row of barren and specialised stamens, adapted by their size and colour for attracting the fertilising insects; and these barren and specialised stamens are what we commonly call petals.

As the stamens of almost all flowers, certainly of all the oldest and simplest flowers, are yellow, it would seem naturally to follow that the earliest petals would be yellow too. When the stamens of the outer row were flattened and broadened into peta's, there would be no particular reason why they should change their colour; and, in the absence of any good reason, they doubtless retained it as before. Indeed, the earliest and simplest types of existing flowers are almost always yellow, seldom white, and never blue; and this in itself would be sufficient ground for believing that yellow was the original colour of all petals. But as it is somewhat heretical to believe, contrary to the general run of existing scientific opinion, that petals are derived from flattened stamens, instead of from simplified and attenuated leaves, it may be well to detail here 
the reasons for this belief. For if the petals were originally a row of altered stamens set apart for the special function of attracting insects, it would be natural and obvious why they should begin by being yellow; but if they were originally a set of leaves, which became thinner and more brightly coloured for the same purpose, it would be difficult to see why they should first have assumed any one colour rather than another.

The accepted doctrine as to the nature of petals is that

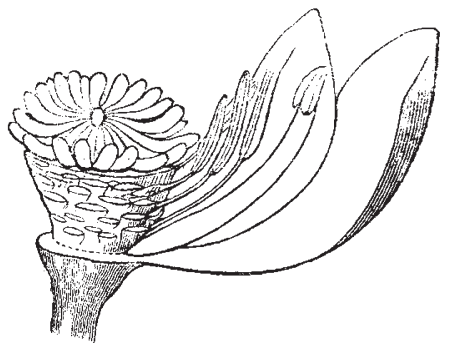

FIG. I.-Transition from stamens to petals in the white water lily.

discovered by Wolf and subsequently rediscovered by Goethe, who held that all the parts of the flower were really modified leaves, and that a gradual transition could be traced between them, from the ordinary leaf, through the stem-leaf and the bract, to the sepal, the petal, the stamen, and the carpel. Now, if we look at most modern flowers, such a transition can undoubtedly be observed; and sometimes it is very delicately graduated, so
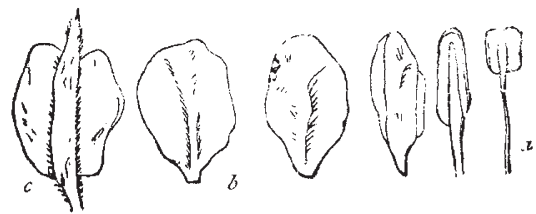

FIG. 2.-Transition from stamen $(a)$ to petal $(b)$ and sepal $(c)$ in fluwer of double rose.

that you can hardly say where each sort of leaf merges into the next. But, unfortunately for the truth of the theory as ordinarily understood, we now know that in the earliest flowers there were no petals or sepals, but that primitive flowering plants had simply leaves on the one hand, and stamens and ovules on the other. The oldest types of flowers at present surviving, are certain gymnosperms, such as the cycads, of which the well-known

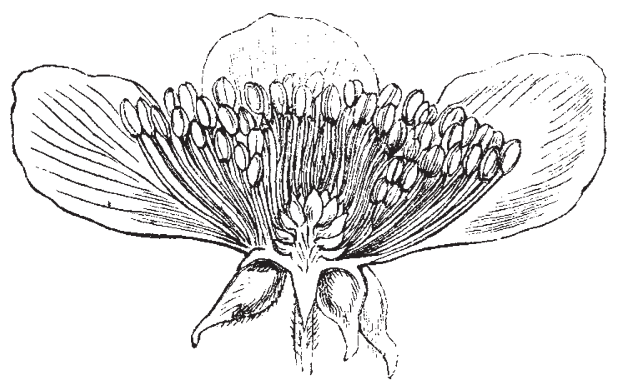

FIG. 3.-Vertical section of bramble (white).

Zamias of our conservatories may be regarded as good examples. These have only naked ovules on the one hand, and clusters of stamens in a sort of cone on the other. The gymnosperms are geologically earlier than any other flowering plants. But, if petals and sepals are later in origin than stamens and carpels, we can hardly say that they mark the transition from one form to the otter, any more than we can say that Gothic architecture marks the transition from the Egyptian style to the classical Greek. It is not denied, indeed, that the stamen and the ovary are themselves by origin modified leavesthat part of the Wolfian theory is absolutely irrefutablebut with the light shed upon the subject by the modern doctrine of evolution, we can no longer regard petals and sepals as intermediate stages between the two. The earliest flowering plants had true leaves on the one hand,

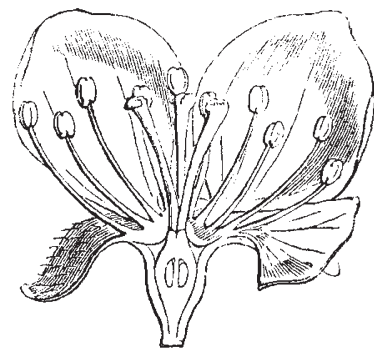

FIG. 4.-Vertical section of apple blossom (pinky white).

and specialised pollen-bearing or ovule-bearing leaves on the other hand, which latter are what in their developed forms we call stamens and carpels; but they certainly had no petals at all, and the petals of modern flowers have been produced at some later period.

All stamens show a great tendency easily to become petaloid, that is to say, to flatten out their filament, and finally to lose their anthers. In the waterlilies we can

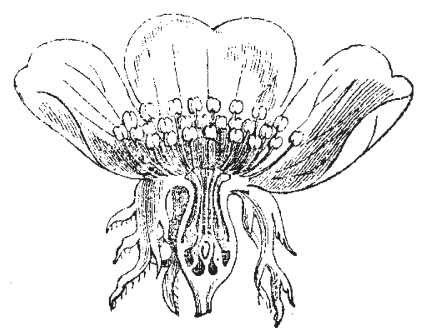

F IG. 5.-Vertical section of dog-rose (bright pink).

trace a regular gradation from the perfect stamen to the perfect petal. Take for example our common English white Nymphoca alba (Fig. I). In the centre of the flower we find stamens of the ordinary sort, with rounded filaments, and long yellow anthers; then, as we move outward, we find the filaments growing flatter and broader, and the anthers less and less perfect ; next we find a few stamens which look exactly like petals, only that they have two abortive

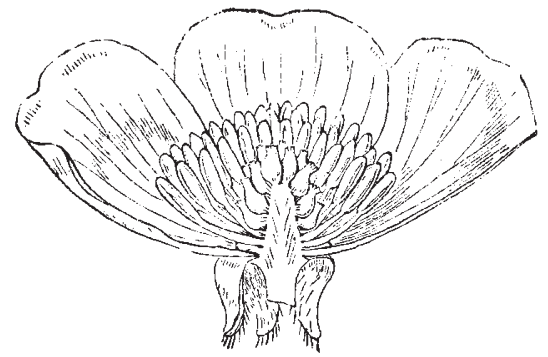

FIG. 6.-Vertical section of buttercup (primitive yellow).

anthers stuck awkwardly on to their summits; and, finally, we find true petals, broad and flat, and without any trace of the anthers at all. Here in this very ancient though largely modified flower we have stereotyped for us, as it were, the mode in which stamens first developed into petals, under stress of insect selection.

"But how do we know," it may be asked, "that the 
transition was not in the opposite direction? How do we know that the waterlily had not petals alone to start with, and that these did not afterwards develop, as the Wolfian hypothesis would have us believe, into stamens?" For a very simple reason. The theory of Wolf and Goethe is quite incompatible with the doctrine of development, at least if accepted as a historical explanation (which Wolf and Goethe of course never meant it to be). Flowers can

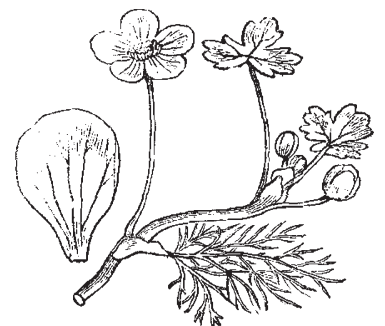

Fic. 7--Water crowfoot (white with yellow certre).

and do exist without petals, which are no essential part of the organism, but a mere set of attractive coloured advertisements for alluring insects; but no flower can possibly exist without stamens, which are one of the two essential reproductive organs in the plant.

Indeed, if we examine closely the waterlily petals, it is really quite impossible to conceive of the transition as taking place from petals to stamens, instead of from stamens to petals. It is quite easy to understand how the

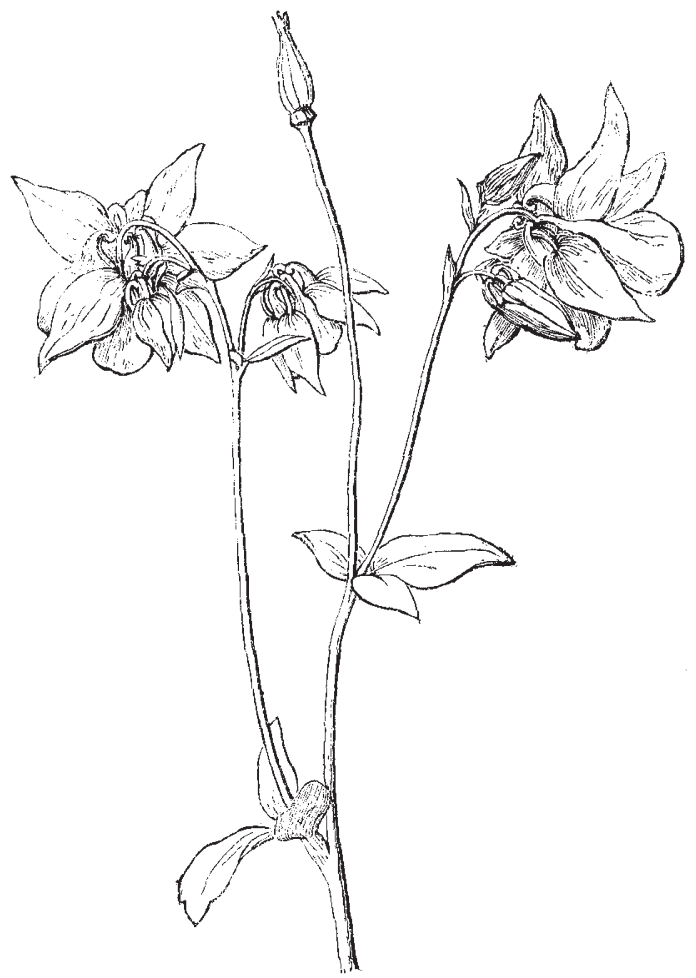

Fig. 8.-Columbine (bluish purple).

filament of an active stamen may become gradually flattened, and the anthers progressively void and functionless; but it is very difficult to understand how or why a petal should first begin to develop an abortive anther, and then a partially effective anther, and at last a perfect stamen. The one change is comprehensible and reasonable, the other change is meaningless and absurd.

In many other cases besides the waterlily, we know that stamens often turn into petals. Thus the numerous coloured rays of the Mesembryanthemums are acknowledged by many botanists to be flattened stamens. In Canna, where one anther-cell is abortive, the filament of the solitary stamen becomes petaloid. In the ginger order, one outer whorl of stamens resembles the tubular

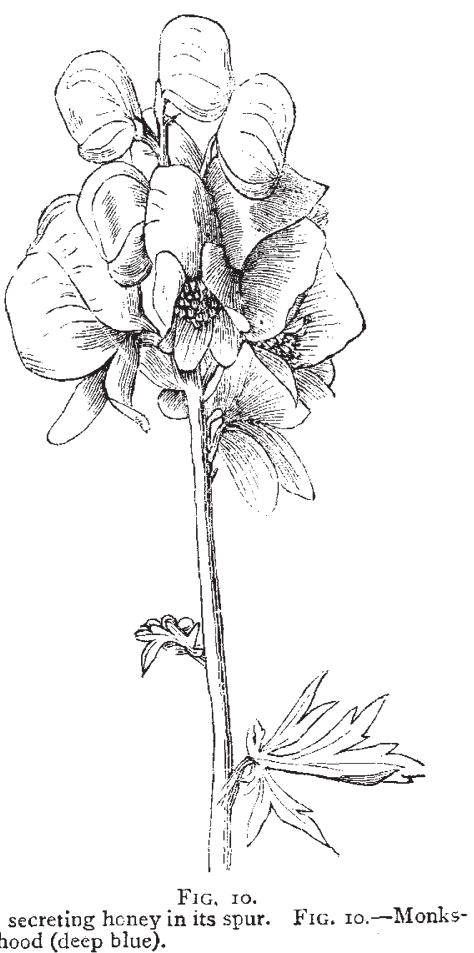

FIG. 9.-Petal of columbine, secreting honey in its spur. FIG. Io.-Monks-
hood (deep blue).

corolla, so that the perianth seems to consist of nine lobes instead of six. In orchids, according to Mr. Darwin, the lip consists of one petal and two petaloid stamens of the outer whor In double roses (Fig. 2) and almost all other double flowers the extra petals are produced from the stamens of the interior. In short, stamens generally can be

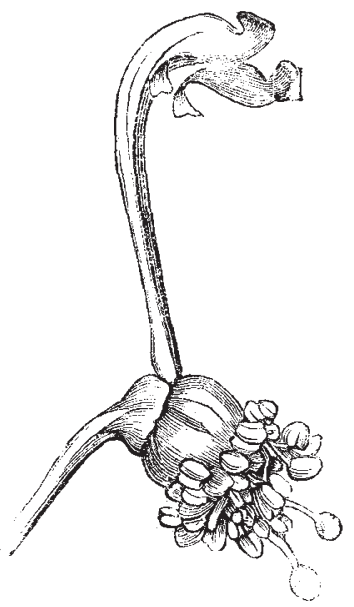

FIG. II. - Petals of monkshood modified into nectaries.

readily converted into petals, especially in rich and fertile soils or under cultivation. The change is extremely common in the families of Ranunculacee, Papaveracea, Magnoliacee, Malvacece, and Rosacece, all very simple types. Looking at the question as a whole, we can see how petals might easily have taken their origin from stamens, 
while it is difficult to understand how they could have taken their origin from ordinary leaves-a process of which, if it ever took place, no hint now remains to us.

In a few rare instances, petals even now show a slight tendency to revert to the condition of fertile stamens. In Monandra fistulosa the lower lip is sometimes prolonged into a flament bearing an anther : and the petals of shepherd's-purse (Capsella bursa-pastoris) have been observed antheriferous.

But if the earliest petals were derived from flattened stamens, it would naturally follow that they would be for the most part yellow in colour, like the stamens from which they took their origin. How, then, did some of them afterwards come to be white, orange, red, purple, lilac, or blue?

The different hues assumed by petals are all, as it were, laid up beforehand in the tissues of the plant, ready to be brought out at a moment's notice. And all flowers, as we know, easily sport a little in colour. But the question is, do their changes tend to follow any regular and definite order? Is there any reason to believe that the modification runs from any one colour towards any other? Apparently, there is. All flowers, it would seem, were in their earliest form yellow; then some of them became white; after that, a few of them grew to be red or purple; and, finally, a comparatively small number acquired various shades of lilac, mauve, violet, or blue.

Some hints of a progressive law in the direction of a colour-change from yellow to blue are sometimes afforded us even by the successive stages of a single flower. For example, one of our common little English forget-menots, Myosotis versicolor, is pale yellow when it first opens ; but as it grows older, it becomes faintly pinkish, and ends by being blue like the others of its race. Now, this sort of colour-change is by no means uncommon; and in almost all known cases it is always in the same direction, from yellow or white, through pink, orange, or red, to purple or blue. Thus, one of the wall-flowers, Cheiranthus chamaleo, has at first a whitish flower, then a citron-yellow, and finally emerges into red or violet. The petals of Stylidium fruticosum are pale yellow to begin with, and afterwards become light rose-coloured. An evening primrose, Enothera tetraptera, has white flowers in its first stage, and red ones at a later period of development. Cobca scandens goes from white to violet; Hibiscus mutabilis from white through flesh-coloured, to red. The common Virginia stock of our gardens (Malcolmia) often opens of a pale yellowish green; then becomes faintly pink; afterwards deepens into bright red; and fades away at last into mauve or blue. Fritz Müller noticed in South America a Lantana, which is yellow on its first day, orange on the second, and purple on the third. The whole family of Boraginacea begin by being pink, and end by being blue. In all these and many other cases the general direction of the changes is the same. They are usually set down as due to varying degrees of oxidation in the pigmentary matter.

If this be so, there is a good reason why bees should be specially fond of blue, and why blue flowers should be specially adapted for fertilisation by their aid. For bees and butterflies are the most highly adapted of all insects to honey-seeking and flower-feeding. They have themselves on their side undergone the largest amount of specialisation for that particular function. And if the more specialised and modified flowers, which gradually fitted their forms and the position of their honey-glands to the forms of the bees or butterflies, showed a natural tendency to pass from yellow through pink and red to purple and blue, it would follow that the insects which were being evolved side by side with them, and which were aiding at the same time in their evolution, would grow to recognise these developed colours as the visible rymbols of those flowers from which they could obtain the largest amount of honey with the least possible trouble. Thus it would finally result that the ordinary unspecialised flowers, which depended upon small insect riff-raff, would be mostly left yellow or white; those which appealed to rather higher insects would become pink or red; and those which laid themselves out for bees and butterflies would grow for the most part to be purple or blue.

Now, this is very much what we actually find to be the case in nature. The simplest and earliest flowers are those with regular, symmetrical open cups, like the Ranunculus genus, the Potentzllas, and the Alsinea or chickweeds, which can be visited by any insects whatsoever: and these are in large part yellow or white. A little higher are flowers, like the campions or Silenea, and the stocks (Matthiola), with more or less closed c pz, whose honey can only be reached by more specialised insects; and these are oftener pink or reddish. More profoundly modified are those irregular one-sided flowers, like the violets, peas, and orchids, which have assumed special shapes to accommodate bees or other specific honey-seekers; aud these are often purple and not infrequently blue. Highly specialised in another way are the flowers like harebells (Campanula), scabious (Dipsacea). and heaths (Ericacece), whose petals have all coalesced into a tubular corolla ; and these might almost be said to be usually purple or blue. And, finally, highest of all are the flowers, like labiates (rosemary, Salvia, \&c.) and speedwells (Veronica, whose tubular corolla has been turned to one sice, thus combining the unite 1 petals with the irregular shape; and these are almost invariably purple or blue.

The very earliest types of angiospermous flowers no $v$ remaining are those in which the carpels still exist in a separate form, instead of being united into a single compound ovary. Among Dicotyledons, the families, some of whose members best represent this primitive stage, are the Rosacece and Ranunculacee; among Monocotyledons, the Alismacer. We may conveniently begin with the first group.

The roses form a most instructive family. As a whole they are not very highly developed flowers, since all of them have simple, open, symmetrical blossoms, generally with five distinct petals. But of all the rose tribe, the Potentillea, or cinquefoil group, seem to make up the most central, simple, and primitive members. They are simple low, creeping weeds, and their flowers are of the earliest symmetrical pattern, without any specialisation of form, or any peculiar adaptation to insect visitors. Now among the potentilla group, nearly all the blossoms have yellow petals, and also the filaments of the stamens yellow, as is likewise the case with the other early allied forms, such as agrimony (Agrimonia Eupatoria), and herb-bennet (Geum urbanum). Among our common yellow species are Potentilla reptans (cir quefoil), $P$. tormentilla, $P$. argentea, $P$. verna, $P$. fruticosa, and $P$. anserina. Almost the only white potentillas in England are the barren strawberry ( $P$. fragariastrum), and the true strawberry (Fragraria vesca), which have, in many ways, diverged more than any other sfecies from the norma of the race. Water-avens (Geum rivale), how. ever, a close relative of herb-bennet, has a dusky purplish tinge ; and Sir John Lubbock notes that it secretes honey, and is far oftener visited by insects than its kinsman. The bramble tribe (Rubece), including the blackberry (Fig. 3), raspberry, and dewberry, have much larger flowers than the potentillas, and are very greatly frequented by winged visitors. Their petals are usually pure white, of ten with a pinky tinge, especially on big, well-grown blossoms. One step higher, the cherries and apples (though genetically unconnected), have very large and expanded petals (Fig. 4), white toward the centre, but blushing at the edges into rosy pink or bright red. Finally, the true roses (Fig. 5), whose flowers are the most developed of all, have usually broad pink petals (like those of our own 
dog-rose, Rosa canina, $R$. villosa, R. rubiginosa, \&c.), which in some still bigger exotic species become crimson or damask of the deepest dye. They are more sought after by insects than any others of their family.

Now, if we look closely at these facts we see that they have several interesting implications. The yellow potentillas have the very simplest arrangement of the carpels in the whole family, and their fruit is of the most primitive character, consisting only of little dry separate nuts. They have altered very little from their primitive type. Accordingly almost all the genus is yellow; a very few members only are white; and these in their habits so far vary from the rest that they have very erect flowers, and three leaflets instead of five or more to each leaf. One of them, the strawberry, shows still further marks of special differentiation, in that it has acquired a soft, pulpy, red fruit, produced by the swelling of the receptacle, and adapted to a safer mode of dispersal by the aid of birds. This group, however, including Geum, cannot claim to be considered the earliest ancestral form of the roses, because of its double calyx, which is not shared by other members of the family, as it would be if it had belonged to the actual common ancestor. In that respect, agrimony more nearly represents the primitive form, though its tall habit and large spikes of flowers show that it also has undergone a good deal of modification. Nevertheless, the yellow members of the potentilla group, in their low creeping habit, their want of woodiness, and their simple fruit, certainly remain very nearly at the primitive ancestral stage, and may be regarded as very early types of flowers indeed. It is only among handsome and showy exotic forms which have undergone a good deal more modification, that we get brilliant red-flowered species like the East Indian $P$. nepalensis and $P$. atropurpurea.

But as soon as the plants rise a little in the scale, and the flowers grow larger, we get a general tendency towards white and pink blossoms. Thus the Prunece have diverged from the central stock of the rose family in one direction, and the Pomea and Rosece in another; but both alike begin at once to assume white petals; and as they lay themselves out more and more distinctly for insect aid, the white passes gradually into pink and rose colour. To trace the gradations throughout, we see that the Rubea or brambles are for the most part woody shrubs instead of being mere green herbs, and they have almost all whitish blossoms instead of yellow ones; but their carpels still remain quite distinct, and they seldom rise to the third stage of pinkiness; when they do, it is generally just as they are fading, and we may lay it down as a common principle that the fading colours of less developed petals often answer to the normal colours of more developed. In the Prunea, again, the development has gone much further, for here most of the species are trees or hard shrubs, and the number of carpels is reduced to one. They have a succulent fruit-a drupe, the highest typeand though the flower contains two ovules, the ripe plum has only one seed, the other having become abortive. All these are marks of high evolution: indeed, in most respects the Prunece stand at the very head of the rose family, but the petals are seldom very expanded, and so, though they are usually deeply tinged with pink in the cherry (Prunus cerasus), and still more so in larger exotic blossoms, like the almond, the peach, and the nectarine, they seldom reach the stage of red. Our own sloe $(P$. communis) has smallish white flowers, as has also the Portugal laurel ( $P$. lusitanicus). In these plants, in fact, higher development has not largely taken the direction of increased attraction for insect fertilisers; it has mainly concentrated itself upon the fruit, and the devices for its its dispersal by birds or mammals. In the Rosece, on the other band, though the fruit is less highly modified, the methods for insuring insect fertilisation are carried much further. There are several carpels, but they are inclosed within the tube of the calyx, and the petals are very much enlarged indeed, while in some species the styles are united in a column. As regards insect attraction, indeed, the roses are the most advanced members of the family, and it is here accordingly that we get the highest types of coloration, Most of them are at least pink, and many are deep red or crimson. Among the Pomea we find an intermediate type (as regards the flowers alone) between Rosece and Prunea; the petals are usually bigger and pinker than those of the plums; not so big or so pink as those of the true roses. This interesting series exhibits very beautifully the importance as regards coloration of mere expansion in the petals. Taking them as a whole, we may say that the smallest petals in the rose family are generally yellow; the next in size are generally white; the third in order are generally pink; and the largest are generally rose-coloured or crimson.

Even more primitive in type than the Rosacece are the lowest members of the Ranunculacea, or buttercup family, which perhaps best of all preserve for us the original features of the early dicotyledonous flowers. The family is also more interesting than that of the roses, because it contains greater diversities of development, and accordingly covers a wider range of colour, its petals varying from yellow to every shade of crimson, purple, and blue. The simplest and least differentiated members of the group are the common meadow buttercups, forming the genus Ranunculus (Fig. 6), which, as everybody knows, have five open petals of a brilliant golden hue. Nowhere else is the exact accordance in tint between stamens and petals more noticeable than in these flowers. The colour of the filaments is exactly the same as that of the petals; and the latter are simply the former a little expanded and deprived of their anthers. We have several English meadow species, all with separate carpels, and all very primitive in organisation, such as $R$. acris (the central form), $R$. bulbosus, $R$. repens, $R$. flammula, $R$. sceleratus, $R$. auricomus, $R$. philonotis, \&c. In the lesser celandine or pilewort, $R$. ficaria, there is a slight divergence from the ordinary habit of the genus, in that the petals, instead of being five in number, are eight or nine, while the sepals are only three; and this divergence is accompanied by two slight variations in colour: the outside of the petals tends to become slightly coppery, and the flowers fade white, much more distinctly than in most other species of the genus.

There are two kinds of buttercup in England, however, which show us the transition from yellow to white actually taking place under our very eyes. These are the watercrowfoot, $R$, aquatilis, and its close ally, the ivy-leaved crowfoot, $R$. hederaceus, whose petals are still faintly yellow toward the centre, but fade away into primrose and white as they approach the edge (Fig. 7). We have already noticed that new colours usually appear at the outside, while the claw or base of the petal retains its original hue; and this law is strikingly illustrated in these two crowfoots. White flowers of the same type as those of water-crowfoot are very common among aquatic plants of like habit, and they seem to be especially adapted to water-side insects.

In many Ramunculacee there is a great tendency for the sepals to become petaloid, and this peculiarity is very marked in Caltha palustris, the marsh-marigold, which has no petals, but bright yellow sepals, so that it looks at first sight exactly like a very large buttercup.

The clematis and anemone, which are more highly developed, have white sepals (for the petals here also are suppressed), even in our English species; and exotic kinfs varying from pink to purple are cultivated in our flower-gardens.

It is among the higher ranunculaceous plants, however, that we get the fullest and richest coloration. Columbines (Aquilegia), are very specialised forms of the buttercup type (Fig. 8). Both sepals and petals are brightly coloured, while the latter organs are produced above into 
long, bow-shaped spurs, each of which secretes a drop of honey (Fig. 9). The carpels are also reduced to five, the regularity of number being itself a common mark of advance in organisation. Various columbines accordingly range from red to purple, and dark blue. Our English species, $A$. vulgaris, is blue or dull purple, though it readily reverts to white or red in cultivated varieties. Even the columbine, however, though so highly specialised, is not bilaterally but circularly symmetrical. This last and highest mode of adaptation to insect visits is found in larkspur (Delphinium ajacis), and still more developed in the curious monkshood (Aconitum napellus), Fig. Io. Now larkspur is usually blue, though white or red blossoms sometimes occur by reversion; while monkshood is one of the deepest blue flowers we possess. Both show very high marks of special adaptation; for besides their bilateral form, Deiphinium has the number of carpels reduced to one, the calyx coloured and deeply spurred, and three of the petals abortive; while Aconitum has the carpels reduced to three and partially united into a compound ovary, the upper sepals altered into a curious coloured hood or helmet, and the petals considerbly modified. All these very complex arrangements are definitely correlated with the visits of insects, for the two highly abnormal petals under the helmet of the monkshood (Fig. II) produce honey, as do also the two long petals within the spur of the larkspur. Both flowers are also specially adapted to the very highest class of insect visitors. Aconitum is chiefly fertilised by bees; and Sir John Lubbock observes that "Anthophora pilipes and Bombus hortorum are the only two North European insects which have a proboscis long enough to reach to the end of the spur of Delphinium elatum. A. pilipes, however, is a spring insect, and has already disappeared, before the Delphinium comes into flower, so that it appears to depend for its fertilisation entirely on Bombus hortorum."

\section{( To be continued.)}

GRANT ALLEN

\section{FREDERIC KASTNER}

FREDERIC KASTNER, who is known to the scientific world as the inventor of the Pyrophone, has recently died, as we announced at the time, at the early age of thirty years. He was the son of an Alsacian composer of some merit, Georges Kastner, and was himself an accomplished musician. Educated partly at Paris and partly at Strasburg, he imbibed a love of science, and at the early age of fourteen years was already assisting his teachers in the chemical laboratory. When seventeen years of age he invented and patented a novel form of electromotor, in which a series of electro-magnets were caused to act in succession upon a rotating arbor. After the war of 870-7 I, in which he was driven from Strasburg, he devoted himself to studying the properties of musical flames. The discovery of Higgins in 1777 , that a hydrogen flame burning within the lower end of an open glass tube could set up a musical note, had been the starting point of a number of hitherto barren attempts by Schaffgotsch and others. Without knowing anything of the experiments of Schaffgotsch, Barrett, or Tyndall, young Kastner set to work to experiment, with the determination to construct a musical instrument on this principle. For two years he worked at the subject, endeavouring to temper the harsh tones of the flames and to produce a purity and constancy in their notes. He tried tubes of different sizes and forms. He varied the form of the gas jet, and essayed to introduce two or more jets into one tube. At last, in $187 \mathrm{I}$, he discovered that when he employed two flames he could control their note at will, being silent when both were close together, but producing sound when they were separated. This phenomenon, which Kastner called the interference of flames, was the real starting-point of Kastner's Pyrophone or Flame-Organ, which he patented in 1873. This organ had for its pipes glass tubes of different lengths, two hydrogen flames burning in each at the proper height. A very simple lever-arrangement served to separate the flames at will. In this form the instrument was presented to the Académie des Sciences at Paris, and publicly exhibited. Two subsequent improvements followed. A circle of small jets of common coal gas was found to answer quite as well as the two hydrogen jets, the circle being constructed so that by a simple mechanical contrivance it could be increased or diminished in size, thus separating or reuniting the flames at will. The second improvement was the application of electric currents and an electromagnetic apparatus enabling the flameorgan to be played at a distance. The first instrument of this kind constructed by Kastner was in the form of a singing-lustre hung from the chandelier in his mother's house. The pyrophone was shown at the Royal Institution in January, 1875, and at the Society of Arts in the succeeding month. It was also shown at the Loan Col. lection of Scientific apparatus at South Kensington in 1876 , and at the Paris Exhibition in 1878 . In 1876 , moreover, an account of the instrument and of the researches which led to its construction was published by Kastner under the title of "Flammes Chantantes." The strange, weird tones produced by the instrument attracted the notice of musicians. Gounod sought to introduce the pyrophone into his opera of "Jeanne d'Arc," and Kœnemann at Baden Baden, in 1879, actually introduced the instrument on one occasion. A decline, however, seized the young inventor, whose strength for some years ebbed slowly away, and he died all too soon to see his invention fairly recognised by the public.

\section{THE NEW AFRICAN EXPEDITION}

$\mathrm{IT}$ is now understood to be quite settled that a ne: African exploring expedition will start next year. The Royal Geographical Society have, as might have been expected, taken the opportunity of $\mathrm{Mr}$. Joseph Thomson's return from the completion of his engagement to the Sultan of Zanzibar to obtain his services as leader, and it is certain that no bettter selection could have been made.

Mr. Thomson will leave England in the Spring of 1883 , and proceed to Zanzibar to organise the expedition. From Mombas, a port on the East African coast, to the north of Zanzibar, he will direct his course straight to Kilimandjaro, and do his best to explore the snowy ranges of this celebrated mountain, which but one European has as yet ever reached. Passing across the waterparting he will then descend through an entirely unknown country to the eastern shore of Lake Victoria Nyanza, and return to the coast by a more northern route, in the course of which it is hoped he may be able to visit Lake Baringo and Mount Kenia-another peak known to run far above the snow-level, but concerning which further details would be very desirable.

As a mere geographical expedition it will be thus seen that the proposed route will be one of great interest, embracing, as it does, the transit through much utterly unknown country, and the exploration of two mysterious snow-crowned mountains, which, according to the usual view of the conformation of the African Continent, appear to be quite out of place in the districts in which they are situated. But still more interesting problems will be solved, if steps are taken to investigate the unknown fauna and flora of Kilimandjaro and Kenia. The animal and vegetable life of these mountains must be entirely different from that of the plains by which they are surrounded. They will prove to have been derived either by modification from the adjacent lower districts, or by immigration from the north-in any case, presenting phenomena of first-rate importance to the student of geographical distribution. 